\title{
Floral Biology and Breeding System of Three Ipomoea Weeds ${ }^{1}$
}

\author{
Biologia Floral e Sistema Reprodutivo de Três Espécies Daninhas de Ipomoea
}

MAIMONI-RODELLA, R.C.S. ${ }^{2}$ and YANAGIZAWA, Y.A.N.P. ${ }^{2}$

\begin{abstract}
The floral biology of three weeds, Ipomoea cairica, I. grandifolia and I. nil (Convolvulaceae), was studied in Botucatu and Jaboticabal, São Paulo, in southeastern Brazil. The three species are melittophilous, with a varied set of floral visitors, but with some overlapping. Cluster analysis using Jacquard similarity index indicated a greater similarity among different plant species in the same locality than among the populations at different places, in relation to floral visitor sets. The promiscuous and opportunistic features of the flowers were shown, with such type of adaptation to pollination being advantageous to weeds since pollinator availability is unpredictable at ruderal environments.
\end{abstract}

Keywords: pollination, bees, morning-glory.

RESUMO - A biologia floral de Ipomoea cairica, I. grandifolia e I. nil - plantas daninhas da família Convolvulaceae - foi estudada em Botucatu e Jaboticabal, Estado de São Paulo, Brasil. As três espécies são melitófilas, apresentando conjuntos de visitantes florais bastante diversificados, embora haja alguma sobreposição entre eles. Com relação aos visitantes florais, a análise de agrupamento, empregando-se o indice de similaridade de Jaccard, indicou maior similaridade entre diferentes espécies de Ipomoea ocorrentes no mesmo local do que entre populações da mesma espécie em diferentes localidades. O caráter promíscuo e oportunista da adaptação à polinização, presente nessas espécies, foi demonstrado, sendo essa adaptação vantajosa para plantas daninhas, uma vez que em ambientes ruderais a disponibilidade de polinizadores é imprevisivel.

Palavras-chave: polinização, abelhas, corda-de-viola.

\section{INTRODUCTION}

Pollination mechanisms are greatly diverse in Angiosperms.Different pollination systems are found among weeds such as anemophily, entomophily, and autogamy. In allogamous or facultative autogamous weed species, pollination is performed by the wind or by nonspecialized pollinators (Baker, 1965). The Convolvulaceae contain species adapted to several pollination syndromes (Vogel, 1954), such as melittophily, which seems to be rather frequent. Ipomoea is a very important genus in this family, constituting of many weeds, some garden ornamentals and edible species. Many Ipomoea weeds are melittophilous with non-specific pollinators (Real, 1981; Stuky \& Bechmann, 1982; Stuky, 1984), but there are some reports on ornithophilous and psicophilous Ipomoea weeds that also show this feature (Machado \& Sazima, 1987). Data obtained in Jaboticabal, São Paulo in southeastern Brazil (Maimoni-Rodella et al., 1982; Maimoni-Rodella, 1991; MaimoniRodella \& Rodella, 1992) confirmed these characteristics by the study of the pollination ecology of I. cairica, I. grandifolia and Ipomoea nil. In these studies, each species showed a well-defined set of visitors but there was some overlapping. In the present study, the set of visitors of these species in Jaboticabal was compared with that observed at Botucatu, both

Recebido para publicação em 23.5.2006 e na forma revisada em 27.2.2007.

Prof. Assist. Dr., Departamento de Botânica, IBB/UNESP, Caixa Postal 510, 18618-000 Botucatu-SP. <rita@ibb.unesp.br>. 
regions located in the state of São Paulo, in southeastern Brazil. This investigation aimed to analyze the similarities between these Ipomoea in relation to sets of pollinators in different localities.

\section{MATERIALS AND METHODS}

The species and the study sites are shown in Table 1. All species are pantropical climbers that occur spontaneously on cultivated land, roadsides and other areas often disturbed by human activity. Detailed descriptions of these Ipomoea weeds were provided by Carrizo \& Sobrero (2001). Ipomoea cairica is a perennial herb with vegetative and sexual reproduction whose pollination biology was studied at Jaboticabal, São Paulo, in southeastern Brazil (2115’22" S, 48॰18'58" W, 575 m altitude) by Maimoni-Rodella et al. (1982). Ipomoea grandifolia and $I$. nil. are annual herbs with sexual reproduction only (Lorenzi, 2000). These two species were previously misidentified in Brazil as Ipomoea aristolochiaefolia and Ipomoea acuminata, respectively (Kissman \& Groth, 1992; Lorenzi, 2000). Under these names, data on their pollination biology at Jaboticabal were published (Maimoni-Rodella, 1991; Maimoni-Rodella \& Rodella, 1992). Further observations on pollination biology of these three Ipomoea species were obtained at Botucatu, São Paulo, also in southeastern Brazil (22 52 '20" S, 48 $26^{\prime} 37^{\prime} \mathrm{W}, 850 \mathrm{~m}$ altitude) as shown in Table 1 .

Botucatu climate is mesothermic, with dry winter and rainy summer, or Koeppen's Cwb (Carvalho et al., 1983). Jaboticabal climate is humid, subtropical with dry winter or Koeppen's Cwa (Aloisi \& Demattê, 1974).
The species were analyzed for reproductive phenology, floral traits (shape, color, texture, size, nectar and scent), floral longevity, number of flowers per inflorescence, breeding systems and pollination ecology. Five to ten individuals were observed in each population (Table 1). Reproductive phenology was monitored every week, recording the beginning, peak (when half or more individuals were blooming) and end of the flowering period. Number of flowers/plant was estimated twice a month in 5-10 individuals in 1980 in Jaboticabal. Measurements of floral parts were based on ten flowers from five individuals.

The species were tested for spontaneous self-pollination according to Dafni (1992). In Jaboticabal, 34 individual flower buds from five individuals of $I$. cairica, 35 buds of I. grandifolia and 25 buds of $I$. nil, both from ten individuals, were isolated in nylon bags just before anthesis. In Botucatu, 30 individual flower buds of I. grandifolia and I. nil, both from ten individuals, received the same treatment and, for the three species, other 30 flowers from five individuals were marked and maintained uncovered to estimate natural fruit-set (control). The study sites are shown in Table 1. Subsequent fruit production was monitored until dispersal phase. The pollen/ ovule ratio $(\mathrm{P} / \mathrm{O})$ was evaluated in 10 preanthesis flower buds following Cruden (1977). Pollen viability was estimated in other 10 preanthesis buds by means of staining samples with aceto-carmine, according to Radford et al. (1974). All these pre-anthesis flower buds were collected at a stage previously known to be reached one day before flower opening, since the pollen is already exposed when the flower opens.

Table 1 - Species and study sites for Ipomoea populations from São Paulo State, Brazil

\begin{tabular}{|c|c|c|c|c|}
\hline Specie & Site & Location and dates of study & Location characteristic & $\begin{array}{l}\text { Number of } \\
\text { individuals }\end{array}$ \\
\hline \multirow{2}{*}{ I. cairica } & Botucatu & Campus Unesp - Rubião Jr. (1990-1991) & Disturbed areas, near forests & 5 \\
\hline & Jaboticabal $^{11}$ & Campus Unesp - FCAV (1980) & Open cultivated areas & 5 \\
\hline \multirow{2}{*}{ I. grandifolia } & Botucatu & Campus Unesp - Lageado (1986-1987) & Cultivated areas surrounded by forests & 10 \\
\hline & Jaboticabal $^{21}$ & Campus Unesp - FCAV (1978-1981) & Open cultivated areas & 10 \\
\hline \multirow{2}{*}{ I. nil } & Botucatu & Campus Unesp - Lageado (1986-1987) & Cultivated areas surrounded by forests & 10 \\
\hline & Jaboticabal $^{\underline{\underline{3}}}$ & Campus Unesp - FCAV (1978-1981) & Open cultivated areas & 10 \\
\hline
\end{tabular}

${ }^{1}$ Maimoni-Rodella et al. (1982); ${ }^{2 /}$ Maimoni-Rodella (1991); ${ }^{3 /}$ Maimoni-Rodella \& Rodella (1992). 
The presence and behavior of floral visitors were monitored by direct observation, and after that, they were classified as pollinators or robbers (sensu Dafni 1992 and Inouye 1980). The observations were performed from early morning (approx. 04:30h) to afternoon (approx. 14:00h), during several days along the study years. Visits were monitored over approx. $50 \mathrm{~h}$ at each Ipomoea species. The visitors were collected and identified. For each visitor, abundance was registered considering the number of recorded visits. For each Ipomoea, visitor relative abundance (RA) was calculated based on the total number of recorded visits. The visitors were considered legitimate pollinators or robbers, based mainly on behavior and also on RA values. The pollinators were considered efficient based on their abundance and behavior at the flowers, that is, they were evaluated in relation to the ability to contact anthers and stigmas. The plant species were compared in relation to floral visitor presence/absence.

The evaluation of similarity between the Ipomoea pollinators was performed using cluster analysis (Ludwig \& Reynolds, 1988). Original matrices were constructed based on the lists of the three Ipomoea pollinators in Jaboticabal and Botucatu. The sample units in these matrices were the Ipomoea species in both localities, and the variables were the 25 main species of pollinators observed in each locality. Qualitative data analysis of pollinators (presence/absence) on each Ipomoea was performed using the Jacquard coefficient for similarity evaluation (Sneath \& Sokal, 1973). The sample units with the highest similarity were clustered (UPGMA), forming dendrograms in which the clusters were hierarchically arranged, with scales indicating similarity level. Delimitation of clusters was made based on a subjective analysis of the dendrograms. The adjustments between the similarity values and those of the corresponding original matrix were provided by the cophenetic correlation coefficient $(\mathrm{r})$.

\section{RESULTS AND DISCUSSION}

Ipomoea cairica bloomed all year round, in a phenological pattern similar to that defined as continual by Newstrom et al. (1994), since the flowering amplitude was not uniform along the year. In the rainy season, I. cairica had a flowering peak which lasted from October to January, and in the dry season, the number of flowers decreased considerably (Figure 1). The other two species showed an annual phenological pattern (sensu Newstrom et al., 1994), blooming from March, in the end of the rainy season, until July, in mid dry season (Figure 1). Thus, there was some overlapping of blooming periods between all species. However, I. cairica and I. grandifolia had flowering peaks occurring at different periods of the year. This flowering behavior may be associated to the avoidance of competition by pollinators, as pointed out by Gentry (1974a, 1974b) in relation to bignon species that share pollinators. Considering the amount of flowers produced by these Ipomoea, they can be regarded as important sources of nutritional rewards to flower visitors, especially in disturbed environments where habitat may become increasingly fragmented (Aizen, 2002). Such resource offer patterns are generally associated with pollination by different bee species (Frankie, 1976).

The three Ipomoea flowers are ephemeral, lasting only one day. Anthesis started around 05:00h and lasted mostly until afternoon (Table 2), when the corollas wilted and fell off. At the opening time, for all species, the stigma was receptive and the anthers were dehisced. According to Gentry (1974a), Bignoniaceae species that flower strongly over a period of 3-8 weeks have these ephemeral flowers and

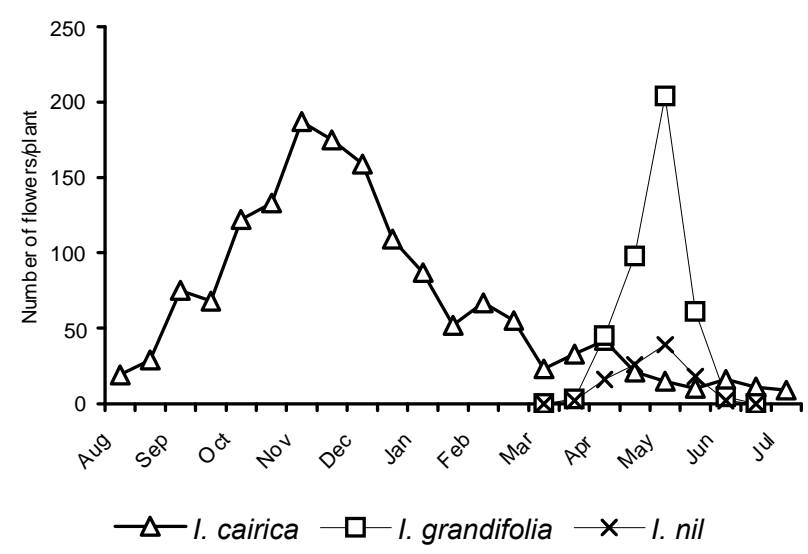

Figure 1 - Flowering phenology of Ipomoea species (Convolvulaceae), Jaboticabal, São Paulo, Brazil.

Planta Daninha, Viçosa-MG, v. 25, n. 1, p. 35-42, 2007 
Table 2 - Floral traits of three Ipomoea species (Convolvulaceae), São Paulo, Brazil

\begin{tabular}{|c|c|c|c|}
\hline Floral traits & I. cairica & I. grandifolia & I. nil \\
\hline \multicolumn{4}{|l|}{ Corolla } \\
\hline Shape & Infundibuliform & Infundibuliform & Infundibuliform \\
\hline Color of limbus & Lilac & Lilac & Sky-blue \\
\hline Color of tube & Dark-violet & Dark -violet & White \\
\hline Texture & Membranaceous & Membranaceous & Membranaceous \\
\hline \multicolumn{4}{|l|}{ Dimensions $(\mathrm{mm})(\mathrm{N}=10)$} \\
\hline Peduncle length & 30 & 25 & 30 \\
\hline Pedicel length & 10 & 5 & 10 \\
\hline Corolla length & 50 & 20 & 50 \\
\hline Limbus diameter & 55 & 20 & 55 \\
\hline Tube diameter & 10 & 9 & 10 \\
\hline Nectar & $\begin{array}{l}\text { Scarce, imbibed in } \\
\text { nectariferous disk }\end{array}$ & $\begin{array}{l}\text { Scarce, imbibed in } \\
\text { nectariferous disk }\end{array}$ & $\begin{array}{l}\text { Scarce, imbibed in } \\
\text { nectariferous disk }\end{array}$ \\
\hline Scent & Imperceptible & Imperceptible & Imperceptible \\
\hline Flower disposition & Erect or inclined & Erect or inclined & Erect or inclined \\
\hline Flower buds/inflorescence $(\mathrm{N}=10)$ & $2-6$ & $2-8$ & $2-6$ \\
\hline Functional flowers/inflorescence $(\mathrm{N}=10)$ & 1 & $1-2$ & 1 \\
\hline 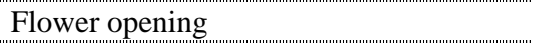 & $05: 30-06: 30 \mathrm{~h}$ & $05: 30-06: 30 \mathrm{~h}$ & $04: 30-05: 30 \mathrm{~h}$ \\
\hline Flower closing & $12: 00-16: 00 \mathrm{~h}$ & $11: 00-12: 00 \mathrm{~h}$ & $10: 00-12: 00 \mathrm{~h}$ \\
\hline Pollen/Ovule Ratio $(\mathrm{N}=10)$ & $1227.05 \pm 444.5$ & $194.9 \pm 19.1$ & $199.9 \pm 14.6$ \\
\hline Fertile pollen $(\%)(\mathrm{N}=10)$ & $84.91 \pm 18.64$ & $97.3 \pm 1.1$ & $97.2 \pm 2.2$ \\
\hline
\end{tabular}

are visited by a wide range of bees, butterflies, hummingbirds and hawkmoths. He defined this phenological pattern as "cornucopia", which can be applied to the studied Ipomoea, specially I. grandifolia and I. nil. For I. cairica, the "cornucopia" pattern seems to be associated with the "steady state" pattern, following Gentry (1974a), since there was a constant production of few flowers all round the year, and one period of several weeks when the flower production was more intense.

Essential Ipomoea floral traits (Table 2, Figure 2) reveal that several of them are characteristics of melittophily, as described by Faegri \& Pijl (1979). The flower colors of these species are attractive to bees, according to Proctor \& Yeo (1973) and Kevan (1979). In all three species, nectar is scarce and produced by a nectariferous disk located at the base of the ovary. The five stamens have different lengths and are disposed around the style, which is terminal and included. This arrangement enhances spontaneous selfpollination because some stamens touch the stigma.
Pollen fertility was high in the three Ipomoea (Table 2). The pollen/ovule ratios indicate that $I$. cairica is alogamous and that I. grandifolia and $I$. nil are facultative autogamous, according to Cruden (1977). These results were confirmed in the breeding system tests (Table 3). Fruit set after spontaneous self-pollination occurred only in I. grandifoliaand I. nil, and the fruit set in openpollinated flowers (control) was lower in I. cairica. Martin (1970) found I. nil to be selffertile and quotes $I$. cairica as self-incompatible. Maimoni-Rodella et al. (1982) reported fruit set failure after spontaneous self-pollination in $I$. cairica, reinforcing the possibility of occurrence of self-incompatibility in this species. Self-incompatibility has been already reported in some Ipomoea species (Stucky \& Beckmann, 1982; Kowyama et al. 2000).

Nectar was the main reward for I. grandifolia and $I$. nil visitors since pollen collection was rarely observed in these flowers. Ipomoea cairica visitors collected both nectar and pollen. Radial corolla symmetry, flower dimension and stamen and stigma disposition enhance nectar access 
by several bees. These visitors can perform both sternotribical and nototribical pollination (sensu Endress, 1994) depending on the way they enter into the corolla tube.

All visitors were active, predominantly active between 08:00 and 12:00h, except in I. cairica, whose flowers lasted some hours more on colder days and were visited until approx. 16:00h. Flowers of these Ipomoea were visited by several species of bees, butterflies, beetles, one Tabanidae and one Scoliidae (Table 4). The floral traits and the variety of pollinators indicate that the three Ipomoea perform promiscuous pollination (sensu Percival, 1965). The most effective pollinators of I. cairica were Ceratina (Crewella) sp., Ceratina sp. 1 and two Halictidae bees in Botucatu and Melitoma segmentaria, Ancyloscelis apiformis, Exomalopsis fulvofasciata and Trigona spinipes in Jaboticabal. In relation to I. grandifolia, the bees Apis mellifera, Ancyloscelis sp., Diadasina riparia, and one fly (Tabanidae) in Botucatu and A. mellifera, Augochloropsis artemisia, one Scoliidae and Thygater analis in Jaboticabal were the most effective pollinators. I. nil had the bees $D$. riparia, Eulaema nigrita, $M$. segmentaria and one fly (Tabanidae), in Botucatu, and $M$. segmentaria, T. analis, Diadasia sp. and E. nigrita, in Jaboticabal, as the most effective pollinators. Many other bees can pollinate these three weeds (Table 4), although less effectively. Melittophilous pollination performed by several bee species was observed in other Ipomoea weeds (Real, 1981; Stucky \& Beckmann, 1982; Galetto et al. 2002). Butterflies, beetles and some bees were robbers (sensu Dafni, 1992) visiting the flowers and not performing pollination. (a)

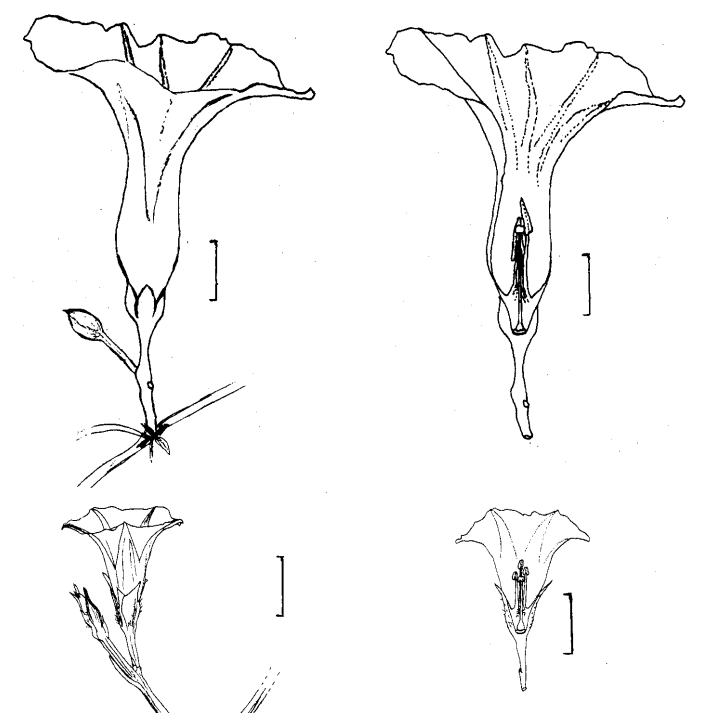

(c)

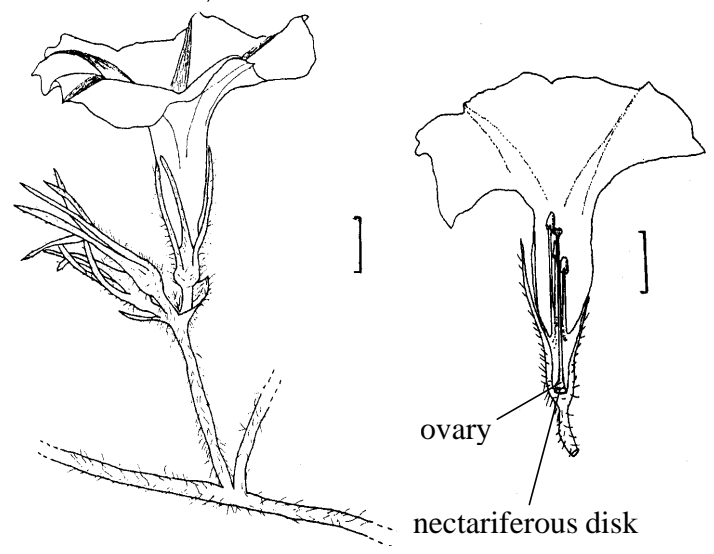

Figure 2 - General view, on the left, and median longitudinal section, on the right, of I. cairica (A), I. grandifolia (B) and Ipomoea nil (C) flowers. Note the nectariferous disk at the ovary basis, the different sizes of the stamens, the arrangement of the anthers around the stigma, and the diameter of the floral tube. Bars $=1 \mathrm{~cm}$.

Table 3 - Fruit set following pollination treatments in Ipomoea species

\begin{tabular}{|c|c|c|c|c|c|c|}
\hline & \multicolumn{2}{|c|}{ Ipomoea cairica } & \multicolumn{2}{|c|}{ Ipomoea grandifolia } & \multicolumn{2}{|c|}{ Ipomoea nil } \\
\hline & Botucatu & Jaboticabal & Botucatu & Jaboticabal & Botucatu & Jaboticabal \\
\hline \multicolumn{7}{|l|}{ Spontaneous self-pollination } \\
\hline Number of bagged buds & - & 34 & 30 & 35 & 30 & 25 \\
\hline Fruit set & - & 0 & 10 & 10 & 18 & 14 \\
\hline$\%$ of success & - & 0 & 33.3 & 28.6 & 60 & 56 \\
\hline \multicolumn{7}{|l|}{ Control } \\
\hline Number of marked buds & 30 & - & 30 & - & 30 & - \\
\hline Fruit set & 17 & - & 22 & - & 26 & - \\
\hline$\%$ of success & 56.7 & - & 73.3 & - & 86.7 & - \\
\hline
\end{tabular}


Table 4 - Floral visitors relative abundance (\%) in three Ipomoea species at Botucatu and Jaboticabal, São Paulo State, Brazil. 1: legitimate visitors; 2: robbers. Numbers in boldface: most efficient pollinators. For each visitor species data in parenthesis are number of visits/total number of visits at the plant

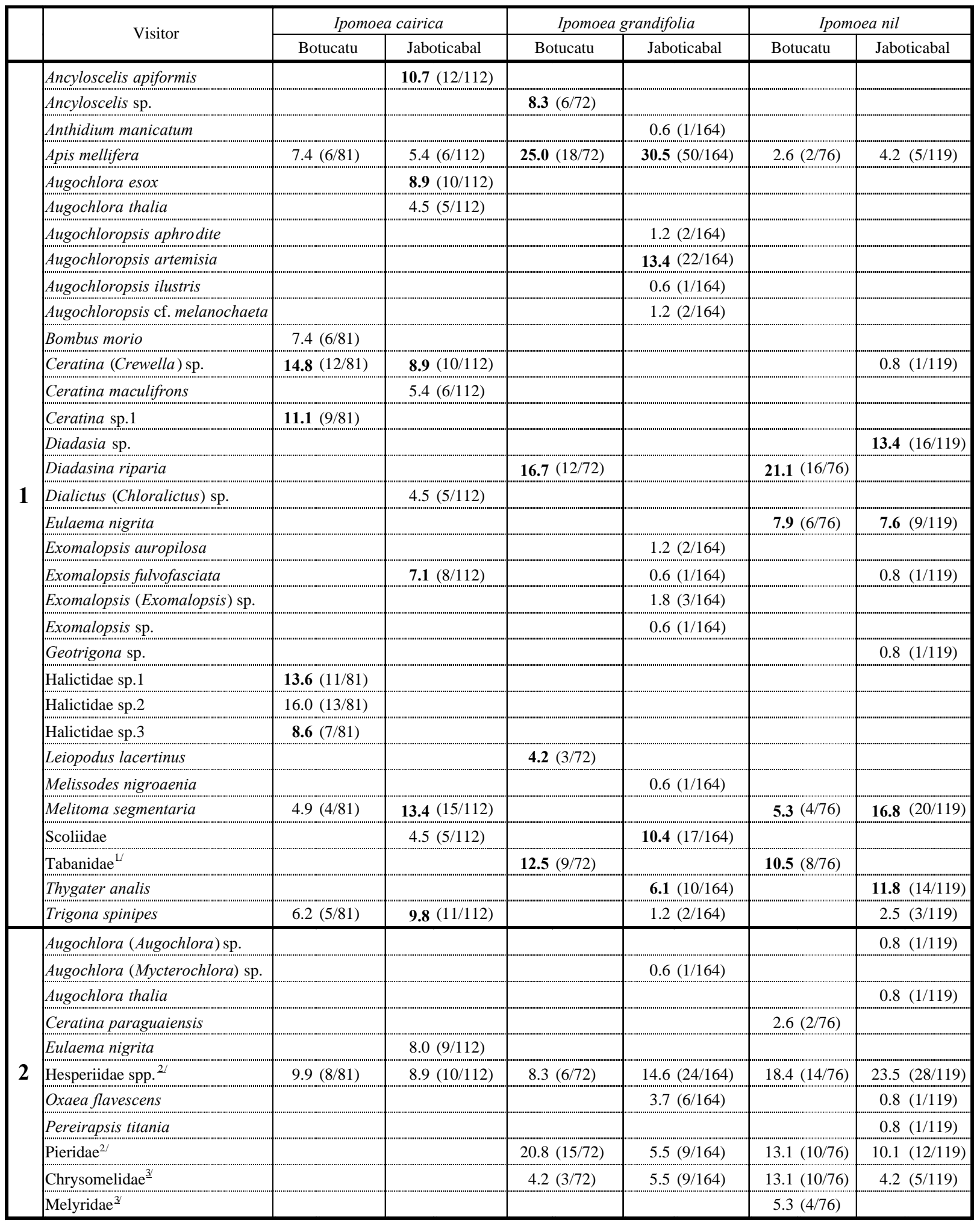

${ }^{1 /}$ Diptera $;{ }^{2 /}$ Lepidoptera; ${ }^{3 /}$ Coleoptera; species without symbol: Hymenoptera. 
The three Ipomoea attracted a greater variety of bee visitors in Jaboticabal. This greater richness of pollinators in weed flowers can be related to reward offer at that site (Table 1 ), considering that in open cultivated areas weeds may be the only available resource, at some particular times. In Botucatu, poor occurrence of pollinators may be due to the fact that the study sites were located near natural forests, which may retain the flower visitors more hardly. Competition for pollinator services including weeds and native plants were reported by Brown et al. (2002). However, in relation to the studied Ipomoea, further studies are needed to clear up these relations.

The studied Ipomoea shared some visitors, but there were some differences in relation to the set of species and abundance of each visitor observed at the different study sites, revealing opportunistic strategy in relation to pollination. In general, higher similarity was observed between different plant species in the same locality than between plant populations of the same species in different localities. This situation can be confirmed by the dendrogram produced by cluster analysis (Figure 3 ). Ipomoea nil and I. grandifolia in Botucatu showed the highest level of similarity, followed by $I$. nil, I. grandifolia and I. cairica in Jaboticabal. At a lower similarity level, I. cairica in Botucatu joined the Jaboticabal group. This situation reveals that the set of I. cairica pollinators is somewhat more conservative

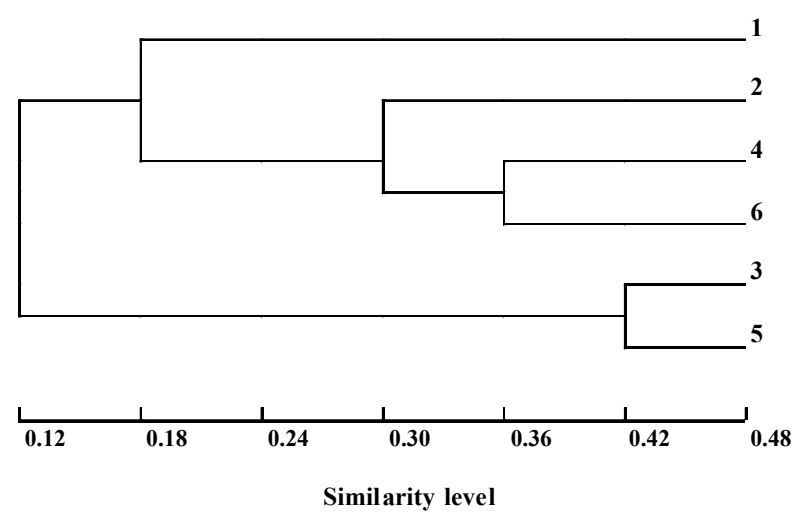

Figure 3 - Cluster analysis dendrogram (UPGMA) considering Jaccard coefficient of similarity among Ipomoea species in relation to sets of floral visitors. 1. I. cairica-Botucatu. 2. I. cairica - Jaboticabal. 3. I. grandifolia - Botucatu. 4. I. grandifolia - Jaboticabal. 5. I. nil-Botucatu. 6. I. nil - Jaboticabal. $(\mathrm{r}=0.85)$. than the other two species. This fact may be related to the reproductive system of $I$. cairica which is alogamous, and thus, dependent on flower visitors to perform pollination. This last consideration needs further investigation.

Finally, the opportunistic pollination feature of the three Ipomoea studied was emphasized since the highest similarities were observed among different species occurring in the same site. The floral traits of these species, in which the resources are easily accessible to visitors, seem to favor promiscuous pollination, as pointed out by Percival (1965). The nonspecificity of these three weeds in relation to pollination is advantageous, considering that, at ruderal environments, pollinator availability is unpredictable (Baker, 1965; 1974); this adaptation is frequently associated to plants living in anthropic, disturbed environments (Valentine, 1978), such as the sites studied in this work.

\section{ACKNOWLEDGEMENTS}

We thank Dr. João M. F. Camargo for the identification of the bees collected in Jaboticabal and Drs. Maria Christina de Almeida and José S. Moure for identification of the bees collected in Botucatu.

\section{LITERATURE CITED}

AIZEN, M. A. Habitat fragmentation, pollinator decline and plant pollination. In: KEVAN. P. G.; IMPERATRIZFONSECA, V. Pollinating bees: the conservation link between agriculture and nature. Brasília: Ministry of Environment, 2002. p. 291-292.

ALOISI, R. R.; DEMATTÉ, J. L. I. Levantamento dos solos da Faculdade de Medicina Veterinária e Agronomia de Jaboticabal. Cientifica, v. 2, p. 123-136, 1974.

BAKER, H. G. Characteristics and modes of origin of weeds. In: BAKER, H. G.; STEBBINS, G. L. (Eds.). The genetics of colonizing species. New York: Academic Press, 1965. p. $147-172$.

BAKER, H. G. The evolution of weeds. Ann. Rev. Ecol. Syst., v. 5, p. 1-24, 1974.

BROWN, B. J.; MITCHELL, R. J.; GRAHAM, S.

Competition for pollination between an invasive species (purple loosestrife) and a native congener. Ecology, v. 83, p. 2328-2336, 2002.

Planta Daninha, Viçosa-MG, v. 25, n. 1, p. 35-42, 2007 
CARRIZO, E. V.; SOBRERO, Y. M. T. Descripción de las especies del género Ipomoea presentes em el area de riego del Rio Dulce, Santiago del Estero, Argentina. Planta Daninha, v. 19, p. 155-161, 2001.

CARVALHO, W. A.; ESPÍNDOLA, C. R.; PACCOLA, A. A. Levantamento de solos da Fazenda Lageado. Botucatu: Universidade Estadual Paulista, 1983. 95 p. (Boletim Científico, 1)

CRUDEN, R. W. Pollen-ovule ratios: a conservative indicator of breeding systems in flowering plants. Evolution, v. 31, p. 32-46, 1977.

DAFNI, A. Pollination ecology: a practical approach. Oxford: Oxford University Press, 1992. p. 32-38.

ENDRESS, P. K. Diversity and evolutionary biology of tropical flowers. Cambridge: Cambridge University Press, 1994. p. 105-121.

FAEGRI, K.; van der PIJL, L. The principles of pollination ecology. 3.ed. London: Pergamon Press, 1979. 244 p.

FRANKIE, G. W. Pollination of widely dispersed trees by animals in Central America, with an emphasis on bee pollination systems. In: BURLEY, J.; STYLES, B. T. (Eds.). Tropical trees variation, breeding and conservation. London: Academic Press. 1976. p. 151-159.

GALETTO, L.; FIONI, A.; CALVIÑO, A. Éxito reproductivo y calidad de los frutos en poblaciones del extremo sur de la distribución de Ipomoea purpurea (Convolvulaceae). Darwiniana, v. 40, p. 25-32, 2002.

GENTRY, A. H. Flowering phenology and diversity in tropical Bignoniaceae. Biotropica, v. 6, p. 64-68. 1974a.

GENTRY, A. H. Co evolutionary patterns in Central American Bignoniaceae. Ann. Mo. Bot. Gard., v. 61, p. $728-759.1974 b$

INOUYE, D. W. The terminology of floral larceny. Ecology, v. 61, p. 1251-1253, 1980.

KEVAN, P. G. Vegetation and floral colors revealed by ultraviolet light: interpretational difficulties for functional significance. Am. J. Bot. v. 66, p. 749-751, 1979.

KISSMAN, K. G.; GROTH, D. Plantas infestantes e nocivas. São Paulo: BASF Brasileira, 1992. p. 504-608.

KOWYAMA, Y.; TSUCHIYA, T.; KAKEDA, K.

Sporophytic self-incompatibility in Ipomoea trifida, a close relative of sweet potato. Ann. Bot., v. 85, p. 191-196, 2000. (Suppl. A).

LORENZI, H. Plantas daninhas do Brasil: terrestres, aquáticas, parasitas e tóxicas. 3.ed. Nova Odessa: Instituto Plantarum, 2000. p. 209-215.

Planta Daninha, Viçosa-MG, v. 25, n. 1, p. 35-42, 2007
LUDWIG J. A.; REYNOLDS, J. F. Statistical ecology. New York: John Wiley \& Sons, 1988. 337 p.

MACHADO, I. C. S.; SAZIMA, M. Estudo comparativo da biologia floral em duas espécies invasoras: Ipomoea hederifolia e I. quamoclit (Convolvulaceae). Rev. Brasil. Biol., v. 47, p. 425-436, 1987.

MAIMONI-RODELLA, R. C. S. Biologia floral de Ipomoea aristolochiaefolia (H.B.K.) Don. (Convolvulaceae).

Turrialba, v. 41, p. 344-349, 1991.

MAIMONI-RODELLA, R. C. S.; RODELLA, R. A. Biologia floral de Ipomoea acuminata Roem. et Schult. (Convolvulaceae). R. Bras. Bot., v. 15, p. 129-133, 1992.

MAIMONI-RODELLA, R. C. S. et al. Polinização em Ipomoea cairica (L.) Sweeth (Convolvulaceae). Naturalia, v. 7, p. 167-172, 1982.

MARTIN, F. W. Self- and interspecific incompatibility in the Convolvulaceae. Bot. Gaz., v. 131, p. 139-144, 1970.

NEWSTROM, L. E.; FRANKIE, G. W.; BAKER, H. G. A new classification for plant phenology based on flowering patterns in lowland tropical rain forest trees at La Selva, Costa Rica. Biotropica, v. 26, p. 141-159, 1994.

PERCIVAL, M. S. Floral biology. London: Pergamon, 1965. $243 \mathrm{p}$.

PROCTOR, M.; YEO, P. The pollination of flowers. New York: Taplinger Publishing, 1973. 418 p.

RADFORD, A. E. et al. Vascular plant systematics. New York: Harper \& Row, 1974. 891 p.

REAL, L. A. Nectar availability and bee foraging on Ipomoea (Convolvulaceae). Biotropica, v. 13, p. 64-69, 1981.

SNEATH, P. H. A.; SOKAL, R. R. Numerical taxonomy. San Francisco: W. H. Freeman, 1973. 350 p.

STUCKY, J. M. Forager attraction by sympatric Ipomoea hederacea and I. purpurea (Convolvulaceae) and corresponding forager behavior and energetics. Am. J. Bot., v. 71, p. 1237-1244, 1984.

STUCKY, J. M.; BECKMANN, R. L. Pollination biology, self-incompatibility and sterility in Ipomoea pandurata (L.) G. F. W. Meyer (Convolvulaceae). Am. J. Bot., v. 69, p. 1022-1031, 1982.

VALENTINE, D. H. The pollination of introduced species, with special reference to the British Isles and the genus Impatiens. In: RICHARDS, A. J. (Ed.). The pollination of flowers by insects. London: Academmic Press, 1978. p. 117-123.

VOGEL, S. Blutenbiologische typen als elements der sippengliederrung. Jena: Fischer, 1954. 338 p. 